\title{
Antifungal Potency of Some Plant Extracts in the Control of White Yam (Dioscorea rotundata poir) Tuber Rot
}

\author{
Gwa $\mathrm{VI}^{1 *}$, Ekefan $\mathrm{EJ}^{2}$ and Nwankiti $\mathrm{AO}^{2}$ \\ ${ }^{1}$ Department of Crop Production and Protection, Federal University, Nigeria \\ ${ }^{2}$ Department of Crop and Environmental Protection, Federal University of Agriculture, Nigeria
}

Submission: September 12, 2017; Published: October 30, 2017

*Corresponding author: Gwa VI, Department of Crop Production and Protection, Federal University, Dutsin-ma, PMB 5001, Katsina State, Nigeria, Tel: +2348039357109; Email: igwa@fudutsinma.edu.ng

\begin{abstract}
Studies were carried out on the effect of some hot aqueous plant extracts using Piper guineense, Zingiber officinale, Azadiracta indica, Carica papaya and Nicotiana tabacum using three concentrations (30,60 and 90g/l) along with a chemical fungicide (mancozeb) at three concentrations $(4,8$ and $12 \mathrm{~g} / \mathrm{l})$ amended in potato dextrose agar (PDA) on in vitro control of $B$. theobromae, causal organism of yam tuber rot. The research was conducted at Advanced Plant Pathology Laboratory, Federal University of Agriculture and Madurai, Nigeria. The pathogen was isolated and identified from rotted white yam tubers. Pathogen city test carried out confirm the organism to be associated with rot in yam tubers. The study showed that $B$. theobromae was able to induce rot on the healthy looking yam tubers. The result also revealed that $N$. tabacum was the least potent extract at $30 \mathrm{~g} / \mathrm{l}, 60 \mathrm{~g} / \mathrm{l}$ and $90 \mathrm{~g} / \mathrm{l}$ with mean percentage value of $19.11 \%, 26.76 \%$ and $38.16 \%$ respectively while the most effective extract was P. guineense with mean value of $81.88 \%, 84.80 \%$ and $92.86 \%$ at $30 \mathrm{~g} / \mathrm{l}, 60 \mathrm{~g} / \mathrm{l}$ and $90 \mathrm{~g} / \mathrm{l}$ respectively. The result also revealed that all the plant extracts were able to inhibit the mycelial of the pathogen with concentration III having the highest inhibitory effect in all the extracts. There was a $100 \%$ inhibition when mancozeb was used irrespective of the level of concentrations and duration of incubation. Treatment of the test plant extracts significantly $(\mathrm{P} \leq 0.05)$ reduced mycelial growth of $B$. theobromae in vitro. The study showed that all the plant extracts showed high potency in the control of $B$. theobromae at varying degrees. These plant extracts can therefore be prepared and used against rot causing fungi of white yam tubers in storage.
\end{abstract}

Keywords: Antifungal; Plant extracts; Yam; Botryodiplodia theobromae; Inhibition; Storage

\section{Introduction}

Yams are the second most important root and tuber crop produced after cassava in West Africa [1-3] reported that Nigeria was the largest producer of yam in the world, producing 35.02 million metric tonnes which constituted about $90 \%$ of total world yam production [4-6]. Reported that over $50 \%$ of yam tubers produced in Nigeria are lost to disease in storage. Fungi organism associated with rotting of yams in storage in Nigeria include Aspergillums flatus, Aspergillums Niger, Botryodiplodia theobromae, Collectotrichum spp, Fusarium oxysporum, Fusarium solani, Geotrichum scandium, Penicillius chrysogenum, Pennicillium digatum, Rhizoctonig spp, Penicillium oxalicum, Trichoderma viride and Rhizopus nodosus [7-12].

Various control measures have been used against rot pathogens of yam in storage. Biological control using Trichoderma harzianum has proved effective in controlling rot pathogens of yam tubers [13]. Chemical pesticides are nonbiodegradable and extremely toxic $[14,15]$. These chemicals have various disadvantages in terms of genotoxicity, hepatotoxicity, reproductive disorders and immunosuppressant [16-19]. The frequent use of these fungicides has led to the emergence of resistant strains of pathogens. Apparently, environmental pollution caused by excessive use of agrochemicals, has increased the public pressure to reduce the use of synthetic fungicides in agriculture [19]. Conversely, pesticides of plant origin are specific biodegradable, cheap, readily available and environmentally safe than synthetic chemicals [5]. Plant extracts could be an alternative to toxic fungicides for controlling plant pathogens $[20,21]$. Since they are composed of various bioactive compounds such as alkaloids, flavonoids, glycosides, phenols, saponins, sterols etc $[13,22]$. The research was therefore, aimed at developing alternative control measures that are non- 
toxic, eco-friendly and cost-effective for the management of $B$. theobromae.

\section{Materials and Methods}

\section{Experimental site}

The experiment was conducted at the Advanced Plant Pathology Laboratory, Federal University of Agriculture, Madurai, Nigeria.

\section{Collection of diseased yam tubers}

Diseased yam tubers of white yam varieties (Rotundata D) showing various disease symptoms of dry rots were obtained from yam farmers from various storage barns in Zaki Biam, Ukum local government area of Benue State, Nigeria which lies between longitudes 90 25E and 9o 28E and latitude 7o $32 \mathrm{~N}$ and $7035 \mathrm{~N}$ respectively. The diseased yam tubers were packaged in sterile polyethylene bags. The samples were protected using wire mesh to prevent rodent attack in the laboratory. Potato Dextrose Agar (PDA) used for growing fungal organisms was the medium used. Test fungus for this study was $B$. theobromae which was most frequently occurring pathogen in the study area.

\section{Isolation of $B$. theobromae}

Tissues of yam were cut at interphase between diseased and healthy parts of the yam tubers. The cut tissues were soaked in $5 \%$ sodium hypochlorite for 2 minutes for surface sterilization and then rinsed in four successive changes of sterile distilled water. The yam pieces were placed on sterile filter papers in the laminar Air flow cabinet to dry for 2 minutes after which the plates were inoculated.

\section{Inoculation}

The dried infected tissues were later picked onto sterile filter paper using a sterile forceps and then wrapped with filter paper for 2-3 minutes. The dried infected tissues were aseptically plated on Petri dishes containing acidified sterile potato dextrose agar (PDA) and the plates were incu $\neg$ bated at ambient room temperature $\left(30 \pm 5{ }^{\circ} \mathrm{C}\right)$ for 7 days to allow for fungal growth.

\section{Characterization and identification}

The fungal colonies growing on the incubated plates were sub-cultured into fresh separate sterile acidified PDA plates and incubated to obtain pure cultures of pathogens. Microscopic examination and morphological characteristics and identification of the isolated pathogen were made and compared with existing authorities $[3,22]$ in order to identify the pathogen.

\section{Pathogen city test}

Healthy looking yam tubers were washed with tap water, rinsed with sterile distilled water and surface sterilized with $5 \%$ sodium hypochlorite for 30 seconds. A sterile $5 \mathrm{~mm}$ cork borer was punched to a depth of $4 \mathrm{~mm}$ into the healthy looking yam tubers and the bored tissues were removed. A five $\mathrm{mm}$ diameter disc from the pure culture of $B$. theobromae was cut and replaced in the holes created. Same procedure was used for the control except that sterile agar discs were used instead of the inoculums in the holes created in the tubers. Petroleum jelly was used to completely seal the holes to prevent contamination by other pathogenic organisms. The inoculated yam tubers were placed in three replications at ambient room temperature $(30 \pm 5$ ${ }^{\circ} \mathrm{C}$ ) under sterile condition. The plates were incubated for 14 days to give enough time for maturity and growth of the fungus after which the tubers were examined for infection and disease development

\section{Preparation of plant extracts}

The method of $[23,24]$ were used with some modifications. Seeds of Piper guineense (Black Pepper), Rhizomes of Zingiber officinale (Ginger), leaves of Azadirachta indica (Neem), leaves of Carica papaya (Pawpaw) and leaves of Nicotiana tabacum (Tobacco) were washed thoroughly with cold running tab water, air-dried and separately grounded into fine powder using a mortar. Hot water $\left(100^{\circ} \mathrm{C}\right)$ extraction was obtained by adding $30 \mathrm{~g}, 60 \mathrm{~g}$ and $90 \mathrm{~g}$ of the powder of each plant extracts to 1litre of sterile distilled water separately in $1000 \mathrm{ml}$ Pyrex flask. These were left for 24 hours and subsequently filtered through four fold of sterile cheese cloth. The filtrates obtained were used as the plant extracts in the experiment. Mancozeb was prepared in sterile distilled water at $4 \mathrm{~g} / \mathrm{l}, 8 \mathrm{~g} / \mathrm{l}$ and $12 \mathrm{~g} / \mathrm{l}$ concentrations respectively. The efficacies of the aqueous plant extracts and chemical fungicide were tested in vitro for their fungicidal activity against tuber dry rot of white yam (Rotundata D) caused by $B$. theobromae.

\section{Measurement of mycelia extension of $B$. theobromae in vitro}

The method of Ahmed et al. [25] was used to determine the fungi toxic effect of plant extracts and chemical fungicide on mycelia extension of the fungus by creating four equal sections on each plate. This involves drawing two perpendicular lines at the bottom of the plate. The point of intersection indicates the centre of the plates. These were done before dispensing PDA into each of the plates. Then $15 \mathrm{ml}$ of the prepared medium was poured into sterilized Petri dishes and $5 \mathrm{ml}$ of each plant extracts and chemical fungicide at the different levels of concentrations were poured into Petri dishes containing the media separately [26] mixed well and allowed to solidify, the solidified medium was inoculated centrally at the point of intersection of the two perpendicular lines drawn at the bottom of the plate. Five mm diameter mycelial discs retrieved from one-week-old fresh cultures grown on PDA plates served as inoculums [27]. Three plates were treated with extract of each plant at respective concentrations. The control experiments had $5 \mathrm{ml}$ of sterile distilled water added to PDA in place of the plant extracts and chemical respectively; the treatments and control were 
incubated for 120 hours at ambient room temperature $(30 \pm 5$ ${ }^{\circ} \mathrm{C}$ ) and measurement of growth as radius of a growing fungal colony were undertaken at intervals of twenty four hours for five times using a transparent ruler. The absence of growth in any of the plates was indicative of the potency of the extract and the chemical fungicide against the test fungus. Fungi toxicity was determined in form of percentage growth inhibition (PGI) according to the method described by [28].

$$
P G I(\%)=\frac{R-R_{1}}{R} \times 100
$$

Where,

PGI $=$ Percent Growth Inhibition

$\mathrm{R}=$ The distance (measured in $\mathrm{mm}$ ) from the point of inoculation to the colony margin in control plate,

$\mathrm{R}_{1}=$ The distance of fungal growth from the point of inoculation to the colony margin in treated plate.

\section{Experimental design and data analysis}

The experimental design was Completely Randomized Design (CRD) with three replicates as described by Nene et al. [29]. Test of variance was calculated using Analysis of variance (ANOVA) and statistical F-tests were evaluated at $\mathrm{P} \leq 0.05$. Differences among treatment means for each measured parameter were further separated using fishers least significance difference (LSD) to determine levels of significance according to Vedashree et al. [30].

\section{Result}

\section{Isolation and identification of $B$. theobromae}

B. theobromae was isolated and identified as one of the pathogen associated with dry rot of white yam (D rotundata) tubers. The cultures of this fungus on potato dextrose agar were initially white to dirty white fluffy mycelial and feathery, becoming grey and eventually black. The underneath plate showed black colour radiating uniformly from the point of inoculation.

\section{Pathogen city test}

Pathogen city test showed that this fungus was able to induce rot on the healthy looking yam tubers. Symptoms of decay were seen on the re-inoculated yam tubers as dry black rot. The yam tubers that were not inoculated with the test fungus did not in any way show any symptom of rot.

\section{Effect of plant extracts and fungicide on the mycelial growth of $B$. theobromae in vitro}

Table 1: Percentage growth inhibition of $B$. theobromae by different concentrations of plant extracts and chemical fungicide after 120 hours of incubation in culture. Means on the same row (for each Plant Extract) with the different superscript are statistically significant ( $p<0.05)$ by period of incubation, ns =not significant.

\begin{tabular}{|c|c|c|c|c|c|c|c|}
\hline \multirow[t]{2}{*}{ Plant Extract } & \multirow[t]{2}{*}{ Concentration $(\mathrm{G} / \mathrm{L})$} & \multicolumn{5}{|c|}{ Period of Incubation (Hours) and Percentage Growth Inhibition (\%) } & \multirow[t]{2}{*}{ Mean } \\
\hline & & 24 & 48 & 72 & 96 & 120 & \\
\hline \multirow{3}{*}{ Piper guineense } & 30 & $100.00 \pm 0.00^{\mathrm{a}}$ & $90.24 \pm 2.31^{\mathrm{b}}$ & $75.67 \pm 2.33^{c}$ & $72.29 \pm 2.51^{c}$ & $71.19 \pm 0.59^{c}$ & $81.88 \pm 3.11$ \\
\hline & 60 & $100.00 \pm 0.0^{\mathrm{a}}$ & $94.84 \pm 2.60^{\mathrm{a}}$ & $79.38 \pm 1.80^{\mathrm{b}}$ & $74.37 \pm 1.81^{\mathrm{b}}$ & $75.42 \pm 0.77^{\mathrm{b}}$ & $84.80 \pm 2.89$ \\
\hline & 90 & $100.00 \pm 0.0^{\mathrm{a}}$ & $100.00 \pm 0.0^{\mathrm{a}}$ & $92.87 \pm 1.23^{\mathrm{b}}$ & $86.68 \pm 1.23^{c}$ & $84.76 \pm 1.35^{c}$ & $92.86 \pm 1.77$ \\
\hline \multirow{3}{*}{ Zingiber officinale } & 30 & $95.24 \pm 4.7^{\mathrm{a}}$ & $89.84 \pm 3.26^{\mathrm{a}}$ & $76.11 \pm 2.00^{\mathrm{b}}$ & $67.44 \pm 1.77^{\mathrm{b}}$ & $70.36 \pm 2.06^{\mathrm{a}}$ & $79.80 \pm 3.13$ \\
\hline & 60 & $96.30 \pm 3.7^{\mathrm{a}}$ & $90.40 \pm 1.90^{\mathrm{a}}$ & $81.75 \pm 2.49^{b}$ & $75.36 \pm 2.42 b$ & $76.28 \pm 0.64^{\mathrm{b}}$ & $84.02 \pm 2.36$ \\
\hline & 90 & $100.00 \pm 0.00^{\mathrm{a}}$ & $92.61 \pm 0.49^{b}$ & $87.90 \pm 1.24 \mathrm{c}$ & $81.62 \pm 1.77^{d}$ & $82.22 \pm 1.34^{\mathrm{d}}$ & $88.87 \pm 1.89$ \\
\hline \multirow{3}{*}{ Azadiracta indica } & 30 & $44.24 \pm 9.07^{\mathrm{a}}$ & $16.30 \pm 10.4^{b}$ & $37.17 \pm 3.14^{\mathrm{a}}$ & $32.51 \pm 2.61^{\mathrm{ab}}$ & $27.16 \pm 2.44^{\mathrm{ab}}$ & $31.51 \pm 3.53$ \\
\hline & 60 & $49.10 \pm 5.47$ & $38.57 \pm 4.11$ & $43.03 \pm 3.52$ & $36.59 \pm 2.28$ & $34.74 \pm 0.75$ & $40.41 \pm 1.94$ \\
\hline & 90 & $73.07 \pm 2.39^{\mathrm{a}}$ & $55.56 \pm 5.56^{\mathrm{bc}}$ & $62.46 \pm 2.11^{\mathrm{b}}$ & $53.87 \pm 3.10^{\mathrm{bc}}$ & $46.62 \pm 1.10^{c}$ & $58.32 \pm 2.68$ \\
\hline \multirow{3}{*}{ Carica papaya } & 30 & $36.20 \pm 11.10$ & $27.46 \pm 7.10$ & $34.43 \pm 5.22$ & $24.22 \pm 3.68$ & $16.11 \pm 0.92$ & $27.69 \pm 3.15$ \\
\hline & 60 & $52.43 \pm 8.8^{\mathrm{a}}$ & $41.11 \pm 4.84^{\mathrm{ab}}$ & $36.95 \pm 4.55^{\mathrm{abc}}$ & $29.28 \pm 4.24^{\mathrm{bc}}$ & $23.72 \pm 1.61^{\mathrm{c}}$ & $36.70 \pm 3.33$ \\
\hline & 90 & $52.43 \pm 8.80$ & $41.11 \pm 4.84$ & $56.16 \pm 4.45$ & $46.86 \pm 0.98$ & $36.43 \pm 1.57$ & $46.60 \pm 2.69$ \\
\hline \multirow{3}{*}{ Nicotiana tabacum } & 30 & $17.78 \pm 9.69$ & $16.83 \pm 5.64$ & $27.02 \pm 7.54$ & $20.32 \pm 1.28$ & $13.61 \pm 3.14$ & $19.11 \pm 2.64$ \\
\hline & 60 & $35.20 \pm 7.71$ & $21.03 \pm 7.22$ & $28.35 \pm 6.21$ & $23.14 \pm 4.46$ & $26.26 \pm 1.60$ & $26.79 \pm 3.72$ \\
\hline & 90 & $37.67 \pm 4.73$ & $30.79 \pm 7.17$ & $44.29 \pm 2.97$ & $36.50 \pm 3.24$ & $41.54 \pm 1.07$ & $38.16 \pm 2.09$ \\
\hline \multirow{3}{*}{ Mancozeb } & 4 & $100.00 \pm 0.00$ & $100.00 \pm 0.00$ & $100.00 \pm 0.00$ & $100.00 \pm 0.00$ & $100.00 \pm 0.00$ & $100.00 \pm 0.00$ \\
\hline & 8 & $100.00 \pm 0.00$ & $100.00 \pm 0.00$ & $100.00 \pm 0.00$ & $100.00 \pm 0.00$ & $100.00 \pm 0.00$ & $100.00 \pm 0.00$ \\
\hline & 12 & $100.00 \pm 0.00$ & $100.00 \pm 0.00$ & $100.00 \pm 0.00$ & $100.00 \pm 0.00$ & $100.00 \pm 0.00$ & $100.00 \pm 0.00$ \\
\hline
\end{tabular}


Table 2: In vitro percentage growth inhibition of $B$. theobromae of some plant extracts and chemical fungicide at different concentrations after 120 hours of incubation. Means on the same column (for each concentration) with different superscript are statistically significant ( $p<0.05$ ).

\begin{tabular}{|c|c|c|c|c|c|c|}
\hline \multirow[t]{2}{*}{ Plant Extract } & \multicolumn{6}{|c|}{ Period of Incubation (Hours) and Mean Percentage Growth Inhibition (\%) } \\
\hline & 24 & 48 & 72 & 96 & 120 & Mean \\
\hline \multicolumn{7}{|c|}{ Concentration I } \\
\hline Azadiracta indica & $44.34 \pm 9.07^{\mathrm{b}}$ & $16.30 \pm 10.40^{\mathrm{b}}$ & $37.17 \pm 3.14^{\mathrm{c}}$ & $32.51 \pm 2.61^{c}$ & $27.16 \pm 2.44^{c}$ & $31.51 \pm 3.53 c$ \\
\hline Carica papaya & $36.20 \pm 11.10^{\mathrm{bc}}$ & $27.46 \pm 7.10^{\mathrm{b}}$ & $34.43 \pm 5.22^{c}$ & $24.22 \pm 3.68^{\mathrm{d}}$ & $16.11 \pm 0.92^{\mathrm{d}}$ & $27.69 \pm 3.15^{c}$ \\
\hline Nicotiana tabacum & $17.78 \pm 9.69^{c}$ & $16.83 \pm 5.64^{\mathrm{b}}$ & $27.02 \pm 7.4^{\mathrm{c}}$ & $20.32 \pm 1.28^{\mathrm{d}}$ & $13.61 \pm 3.14^{\mathrm{d}}$ & $19.11 \pm 2.64^{\mathrm{d}}$ \\
\hline Piper nigrum & $100.00 \pm 0.00^{\mathrm{a}}$ & $90.24 \pm 2.31^{\mathrm{a}}$ & $75.67 \pm 2.33^{b}$ & $72.29 \pm 2.51^{\mathrm{b}}$ & $71.19 \pm 0.59^{b}$ & $81.88 \pm 3.11^{b}$ \\
\hline Zingiber officinale & $95.24 \pm 4.76^{\mathrm{a}}$ & $89.94 \pm 4.76^{\mathrm{a}}$ & $76.11 \pm 2.00^{\mathrm{b}}$ & $67.44 \pm 1.77^{\mathrm{b}}$ & $70.36 \pm 2.06^{b}$ & $79.80 \pm 3.13^{b}$ \\
\hline Mancozeb & $100.00 \pm 0.00^{\mathrm{a}}$ & $100.00 \pm 0.00^{\mathrm{a}}$ & $100.00 \pm 0.00^{\mathrm{a}}$ & $100.00 \pm 0.00^{\mathrm{a}}$ & $100.00 \pm 0.00^{\mathrm{a}}$ & $100.00 \pm 0.00^{\mathrm{a}}$ \\
\hline \multicolumn{7}{|c|}{ Concentration II } \\
\hline Azadiracta indica & $49.10 \pm 5.47^{b}$ & $38.57 \pm 4.11^{\mathrm{b}}$ & $43.03 \pm 3.52^{c}$ & $36.59 \pm 2.28^{c}$ & $34.74 \pm 0.75^{c}$ & $40.41 \pm 1.94^{c}$ \\
\hline Carica papaya & $52.43 \pm 8.80^{\mathrm{b}}$ & $41.11 \pm 4.84^{\mathrm{b}}$ & $36.95 \pm 4.55^{\mathrm{cd}}$ & $29.28 \pm 4.24^{\mathrm{cd}}$ & $23.72 \pm 1.61^{\mathrm{d}}$ & $36.70 \pm 3.33^{c}$ \\
\hline Nicotiana tabacum & $35.20 \pm 1.71^{\mathrm{b}}$ & $21.03 \pm 7.22^{\mathrm{c}}$ & $28.35 \pm 6.21^{\mathrm{d}}$ & $23.14 \pm 4.46^{\mathrm{d}}$ & $26.26 \pm 1.60^{d}$ & $26.79 \pm 3.72^{\mathrm{d}}$ \\
\hline Piper nigrum & $100.00 \pm 0.00^{\mathrm{a}}$ & $94.84 \pm 2.60^{\mathrm{a}}$ & $79.38 \pm 1.80^{\mathrm{b}}$ & $74.37 \pm 1.81^{\mathrm{b}}$ & $75.42 \pm 0.77^{\mathrm{b}}$ & $84.80 \pm 2.89^{\mathrm{b}}$ \\
\hline Zingiber officinale & $96.30 \pm 3.70^{\mathrm{a}}$ & $90.40 \pm 1.90^{\mathrm{a}}$ & $81.75 \pm 2.49^{b}$ & $75.36 \pm 2.42^{\mathrm{b}}$ & $76.82 \pm 0.64^{\mathrm{b}}$ & $84.02 \pm 2.36^{b}$ \\
\hline Mancozeb & $100.00 \pm 0.00^{\mathrm{a}}$ & $100.00 \pm 0.00^{\mathrm{a}}$ & $100.00 \pm 0.00^{\mathrm{a}}$ & $100.00 \pm 0.00^{\mathrm{a}}$ & $100.00 \pm 0.00^{\mathrm{a}}$ & $100.00 \pm 0.00^{\mathrm{a}}$ \\
\hline \multicolumn{7}{|c|}{ Concentration III } \\
\hline Azadiracta indica & $73.07 \pm 2.39^{b}$ & $55.56 \pm 5.56^{\mathrm{b}}$ & $62.46 \pm 2.11^{\mathrm{c}}$ & $53.87 \pm 3.10^{c}$ & $46.62 \pm 1.10^{\mathrm{c}}$ & $58.32 \pm 2.68^{\mathrm{c}}$ \\
\hline Carica papaya & $52.43 \pm 1.57^{c}$ & $41.11 \pm 4.84^{c}$ & $56.16 \pm 4.45^{c}$ & $46.86 \pm 0.98^{d}$ & $36.43 \pm 1.57^{\mathrm{e}}$ & $46.60 \pm 2.69^{d}$ \\
\hline Nicotiana tabacum & $37.67 \pm 4.73^{\mathrm{d}}$ & $30.79 \pm 7.17^{c}$ & $44.29 \pm 2.97^{\mathrm{d}}$ & $36.50 \pm 3.24^{\mathrm{e}}$ & $41.54 \pm 1.07^{\mathrm{d}}$ & $38.16 \pm 2.09^{\mathrm{e}}$ \\
\hline Piper nigrum & $100.00 \pm 0.00^{\mathrm{a}}$ & $100.00 \pm 0.00^{\mathrm{a}}$ & $92.87 \pm 1.95^{\mathrm{ab}}$ & $86.68 \pm 1.23^{b}$ & $84.76 \pm 1.35^{\mathrm{b}}$ & $92.86 \pm 1.77^{\mathrm{b}}$ \\
\hline Zingiber officinale & $100.00 \pm 0.00^{\mathrm{a}}$ & $92.61 \pm 0.49^{\mathrm{a}}$ & $87.90 \pm 1.24^{\mathrm{b}}$ & $81.62 \pm 1.77^{b}$ & $82.22 \pm 1.34^{\mathrm{b}}$ & $88.87 \pm 1.89^{b}$ \\
\hline Mancozeb & $100.00 \pm 0.00^{\mathrm{a}}$ & $100.00 \pm 0.00^{\mathrm{a}}$ & $100.00 \pm 0.00^{\mathrm{a}}$ & $100.00 \pm 0.00^{\mathrm{a}}$ & $100.00 \pm 0.00^{\mathrm{a}}$ & $100.00 \pm 0.00^{\mathrm{a}}$ \\
\hline
\end{tabular}

A. Conc I=30g/L of Plant extract, $4 \mathrm{~g} / \mathrm{l}$ of Mancozeb.

B. Conc $I I=60 \mathrm{~g} / \mathrm{L}$ of Plant extract, $8 \mathrm{~g} / \mathrm{l}$ of Mancozeb.

C. Conc III $=90 \mathrm{~g} / \mathrm{L}$ of Plant extract, $12 \mathrm{~g} / \mathrm{l}$ of Mancozeb.

Table 1 shows that fungicidal potency of plant extracts increased with increase in concentration of the extracts used. The effect of different concentrations of each extract on percentage growth inhibition of $B$. theobromae throughout the period of incubation showed significant difference $(\mathrm{P} \leq 0.05)$. Different levels of concentration showed significant differences among plant extracts throughout the period of incubation (Table 2). Piper guineense and Zingiber officinale were the best plant extracts at concentration I $(30 \mathrm{~g} / \mathrm{l})$ recording mean percentage growth inhibition of $81.88 \%$ and 79.80 respectively after 120 hours in culture. The least effective extracts were $A$. indica, $C$. papaya and $N$. tabacum with mean values of $31.51 \%, 27.69 \%$ and $19.11 \%$ respectively. At concentration II (60g/l) Piper guineense and Zingiber officinale continued to show the highest levels of inhibition of the pathogen with mean percentage growth inhibition of $84.80 \%$ and $84.02 \%$ respectively. It was observed during the study that all the plant extracts exhibited the highest level of effectiveness at concentration of $90 \mathrm{~g} / \mathrm{l}$

with mean percentage growth inhibition of $92.86 \%, 88.87 \%$, $58.32 \%, 46.60 \%$ and $38.16 \%$ for P. guineense, Z. officinale, A. indica, C. papaya and N. tabacum respectively. Plant extracts showed significant differences $(\mathrm{P} \leq 0.05)$ with the chemical at all the levels of concentrations and throughout the period of incubation (Table 2) The most potent plant extracts irrespective of concentration used and duration of incubation were $P$. guineense and $Z$. officinale which showed no significant difference $(\mathrm{P} \leq 0.05)$ between each other at all the levels of concentrations while the least effective plant extracts were $A$. indica, C. papaya and N. tabacum respectively. A. indica and C. papaya showed no significant difference at concentration I and II but differed significantly at concentration III. Mean percentage growth inhibition of three concentrations (I, II and III) showed that $P$. guineense and $Z$. officinale were the most effective extracts in reducing the mycelia growth of $B$. theobromae in culture throughout the period of incubation (Figure 1). 


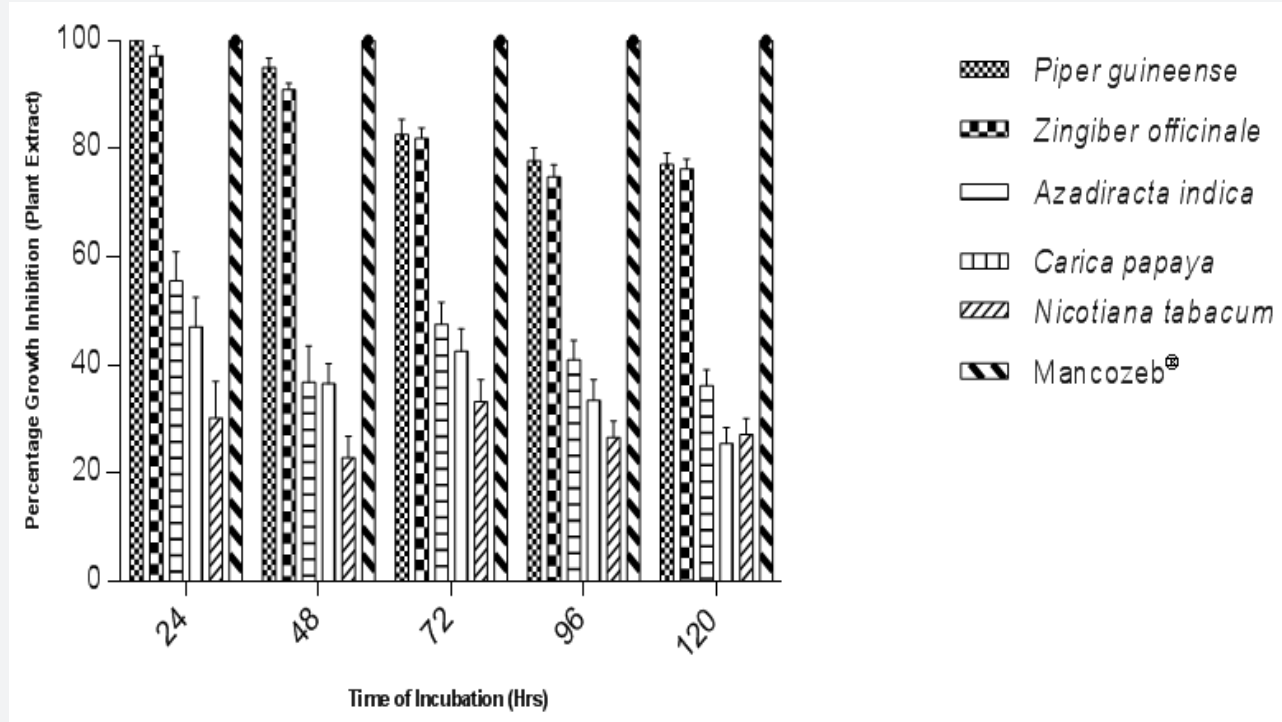

Figure 1: Mean percentage growth inhibition of three concentrations of plant extracts $(30 \mathrm{~g} / \mathrm{l}, 60 \mathrm{~g} / \mathrm{l}$ and $90 \mathrm{~g} / \mathrm{l})$ and mancozeb $(4 \mathrm{~g} / \mathrm{l}, 8 \mathrm{~g} / \mathrm{l}$ and $12 \mathrm{~g} / \mathrm{l})$ on the mycelial growth of $B$. theobromae on period of incubation.

\section{Discussion}

B. theobromae is one of the major fungal pathogenic organisms associated with yam tubers in different parts of the country [6,7]. The different plant extracts showed variations in the inhibition of mycelia growth of the test fungus. Fungicidal potency of plant extracts increased with increase in concentration of the extracts used. Period of incubation also significantly influenced the efficacy of the extracts indicating that the effect of the active compounds of the extracts used were persistent and increased with the incubation period [31]. This report also supports the earlier investigations by Gomez et al. [32] Cochran et al. [33]. According to Amadioha [34] the actions of the antifungal substances present in the plant extracts were fungi static at lower concentrations but became fungicidal at higher concentrations. The effect of different concentrations of each extract on percentage growth inhibition of $B$. theobromae throughout the period of incubation showed significant difference $(\mathrm{P} \leq 0.05)$.

Fungicidal activities of the plant extracts increased as the concentration increased against the test fungus. Antifungal efficacies of some plant extracts in controlling fungal organisms have been extensively studied by other researchers $[35,36]$. Demonstrated the fungi toxic activity of seed extract of $A$ zadirachta indica (neem) and $\mathrm{X}$ aethiopia against the anthracnose fungus (Collectotrichum lindemuthianum) of cowpea [37]. Reduced the growth and sporulaton of fungal pathogens on sweet potato and yam with garlic (Allium sativum) [38] also reported the control of $C$. lingmuthianum using neem seed, leaf, bark and root extract, recording a $100 \%$ inhibition of spore germination and mycelia growth [5]. Control yam rot with leaf of Zingiber officinale. Used the seed extract of $P$. nigrum and inhibited the growth of B. theobromae and Fusarium oxysporum on two varieties of yam
(D. rotundata and D. alata) [23]. Showed that N. tabacum cold extract inhibited the Mycelia of $F$. oxysporum yam rot organism [38]. Used Carica papaya leaf extracts to control incidence of foliar myco-pathogens of groundnut (Arachis hypogea) while [39] inhibited mycelial growth of Alternaria solani, causal organism of yam rot using leaf extracts of Carica papaya.

Singh et al. [20] inhibited the mycelial growth of A. flavus in vitro using extracts of P. nigrum, Z. officinale, A. indica, C. papaya and $N$. tabacum recording mean percentage inhibition of between $53.83 \%$ (C. papaya) and $75.75 \%$ ( $Z$ officinale) at 30g/l; 59.98\% (C. papaya) and 75.74\% (Z. officinale) at 60g/l and $67.91 \%$ ( N. tabacum) and $83.84 \%$ (Z. officinale) at $90 \mathrm{~g} / \mathrm{l}$. In a related experiment, [11] reduced the mycelial growth of Collectotrichum sp with extracts of $Z$. officinale, P. nigrum, A. indica, C. papaya and N. tabacum recording mean percentage inhibition of between $30.39 \%$ (C. papaya) at $30 \mathrm{~g} / \mathrm{l}$ and $82.19 \%$ (P. nigrum) at $90 \mathrm{~g} / \mathrm{l}$. Fungicidal effect of extracts may be due to the lyses of fungal cell wall and cytoplasmic membrane due the liberation of antimicrobial products. It was also reported that plant lytic enzymes act on the fungal cell wall causing breakage of B-1,3 glycan, B-1,6, glycan and chitin polymer [40,41]. The active principle present in plants are influenced by many factors which include the age of plant, extracting solvent, method of extraction and time of harvesting plant materials [4,25]. The presence of fungicidal compounds in P. guineense, Z. officinale, $A$. indica, C. papaya and N. tabacum which caused the inhibition of mycelia growth in vitro of $B$. theobromea agreed with the reports of other workers [5,42].

Increase in concentration of mancozeb has no effect on percentage growth inhibition of the test fungus as the fungus had already attained the highest level of inhibition at the lowest concentration possible [43]. found out that mancozeb 
consistently gave $100 \%$ inhibition (at concentrations of $250 \mathrm{ppm}, 500 \mathrm{ppm}$ and $1000 \mathrm{ppm}$ ) of germination of conidia of Cercospora contraria and Didymosphaeria donacina which caused leaf spot diseases of cluster yam (Dioscorea dumetorum) $[19,20]$ also reported that mancozeb gave $100 \%$ inhibition of mycelial growth of $A$ flavus and Collectotrichum sp respectively at concentrations of $4 \mathrm{~g} / \mathrm{l}, 8 \mathrm{~g} / \mathrm{l}$ and $12 \mathrm{~g} / \mathrm{l}$ in culture. On the other hand, [44-52] observed that increase in the concentration of the chemicals positively correlated with the growth inhibitions.

\section{Conclusion}

The findings have revealed the potential of some plants commonly grown in our environment to posses antifungal effects against $B$. theobromae, causal agent of yam tuber rot. These plants will therefore help to provide alternatives to synthetic fungicides which are often harmful to our environment, non target specific and expensive to purchase.

\section{References}

1. Nweke FI, Ugwu BO, Asadu CL, Ay P (1992) Production cost in the yam based cropping system South-western Nigeria Research monograph No. 6 IITA Ibadan, Nigeria, pp. 4-12.

2. (2008) Food and Agriculture Organization. Production Year Book, FAO, Rome, Italy.

3. Agwu AE, Alu JI (2005) Farmers perceived constraints to yam production in Benue State, Nigeria. Proceedings of the $39^{\text {th }}$ Annual Conference of the Agricultural society of Nigeria, pp. 347-350.

4. Agrios G (2004) Plant pathology ( $5^{\text {th }}$ edn), Elsevier, London, UK, pp. $1-952$.

5. Okigbo RN (2005) Biological Control of Postharvest Fungal Rot of Yam (Dioscorea spp) with Bacillus subtilis. Mycopathologia 159(2): 307314.

6. Okigbo RN, Ajalie AN (2005) Inhibition of some human pathogens with tropical plants extracts Chromolinaena odorata and Citrus aurantifolia and some antibiotics. Int J Mol Med Adv Sci 1(1): 34-40.

7. Okigbo RN, Nmeka IA (2005) Control of yam tuber with leaf extracts of Xylopia aethiopica and Zingiber officinale. Afr J Biotech 4 (8): 804-807.

8. Okoro O, Nwankiti AO (2004) Post-harvest Microbial Rot of Yam in Nigeria. Pathologia, pp. 35-40.

9. Markson AA, Amadioha AC, Omosun G, Madunagu BE, Udo SE, et al. (2012) Control of Botryodiplodia theobromae causing Tissue Rot of White Yam (Dioscorea rotundata Poir). Scholarly Journal of Agricultural Science 2(1): 1-7.

10. Ogunleye AO, Ayansola OT (2014) Studies of Some Isolated Rot-Causing Mycoflora of Yams (Dioscorea Spp). Amer J Microb and Biot 1(1): 9-20.

11. Shiriki D, Ubwa ST, Shambe T (2015) Isolation of nine microorganisms from rotten Dioscorea rotundata (White Yam) and antimicrobial sensitivity test with five plant extracts. Food and Nutrition Sciences 6(10): 825-835.

12. Okigbo NR, Enweremadu CE, Agu CK, Irondi RC, Okeke BC, et al. (2015) Control of white yam (Dioscorea rotundata) rot pathogen using peel extract of water yam (Dioscorea alata). Advances in Applied Science Research 6(10): 7-13.

13. Gwa IV, Bem AA, Okoro JK (2015) Yams (Dioscorea rotundata Poir and D. alata Lam) fungi etiology in katsina ala local government area of benue state, Nigeria. Agri Res \& Tech: Open Access J 3: 38-43.
14. Gwa VI, Nwankiti AO (2017) Efficacy of some plant extracts in in vitro control of Colletotrichum Species, causal agent of yam (Dioscorea rotundata Poir) tuber rot. Asian Journal of Plant Science and Research 7(2): 8-16.

15. Lakshmeesha TR, Sateesh MK, Vedashree S, Sofi MS, Umesha S (2013) Efficacy of botanicals on soybean seed-borne Fusarium equiseti. VCFL Sciences 3(1): 10-16.

16. Yadav SK (2010) Pesticide applications-Threat to ecosystems. J Hum Ecol 32: 37-45.

17. Bolognesi C (2003) Genotoxicity of pesticides: a review of human biomonitoring studies. Mutat Res 543(3): 251-272.

18. Cecchi A, Rovedatti MG, Sabino G, Magnarelli GG (2012) Environmental exposure to organophosphate pesticides: Assessment of endocrine disruption and hepatotoxicity in pregnant women. Ecotox Environ Safe 80: 280-287.

19. Richard S, Moslemi S, Sipahutar H, Benachour N, Seraline GE (2005) Differenential effects of glyphosate and roundup on human placental cells and aromatase. Environ Health Persp 113(6): 716-720.

20. Singh ND, Sharma AK, Dwivedi P, Kumar M, Patil RD, et al. (2011) Immunosuppressive effect of combined citrinin and endosulfan toxicity in pregnant wistar rats. Veterinarski Arhiv 81: 751-763.

21. Bhagwat MK, Datar AG (2014) Antifungal activity of herbal extracts against plant pathogenic fungi. Arch Phytopathology Plant Protect $47(8)$.

22. Gwa VI, Akombo RA (2016) Studies on the antimicrobial potency of five crude plant extracts and chemical fungicide in in vitro control of Aspergillus flavus, causal agent of white yam (Dioscorea rotundata) tuber rot. Journal of Plant Sciences and Agricultural Research 1(1): 1-8.

23. Gwa VI, Nwankiti AO (2017) In vitro Antagonistic Potential of Trichoderma harzianum for biological control of Fusarium moniliforme isolated from Dioscorea rotundata tubers. Virol-mycol 6(2): 166.

24. Okigbo RN, Ogbonnaya UO (2006) Antifungal effects of two tropical plants leaves extract (Ocimum gratissimum and Aframomum melegueta) on post harvest yam (Dioscorea spp). Rot Afr J Biotech 5(9): 727-731.

25. Ahmed KM, Ravinder Reddy CH (1993) A pictorial guide to the identification of seed borne fungi of sorghum, pear millet, finger millet, chickpea, pigeonpea and groundnut. Information Bulletin no. 34 (In En summaries in Fr, Es and Ar) Internation Crops Research Institute for the Semi Arid Tropics, Patancheru AP, India, p. 200.

26. Taiga A, Suleiman MN, Sule W, Olufolaji DB (2008) Comparative in vitro inhibitory effects of cold extracts of some fungicidal plants on Fusarium oxysporium Mycelium 7(18): 3306-3308.

27. Tijjani A, Adebitan SA, Gurama AU, Aliyu M, Dawakiji AY, et al. (2013) Efficacy of some botanicals for the control of wet rot disease on mechanically injured sweet potato caused by Rhizopus stolonifer in bauchi state. Int J Sci Res Pub 3(6): 1-10.

28. Amadioha AC, Obi VI (1999) Control of anthracnose disease of cowpea Cymbopogon citratus and Ocimum gratissimum. Acta phytopathol Entomol Hungerica 34(92): 85-89.

29. Nene ZH, Thapilyal (2002) Management of mushroom pathogens through botanicals. Ind Phytopathol 58: 189-193.

30. Vedashree S, Sateesh MK, Lakshmeesha TR, Sofi MS, Vedamurthy AB, et al. (2013) Screening and essay of extracellular enzymes in Phomopsis azadirachtae causing die-back disease of neem. J Agricultural Technol 9(4): 915-927.

31. Korsten L, De Jager ES (1995) Mode of action of Bacillus subtilis for control of avocado post harvest pathogens. S Afr Avocado Growers Assoc Yearb 18: 124-130. 
32. Gomez KA, Gomez AA (1984) Statistical procedures for Agricultural Research ( $2^{\text {nd }}$ edn), John Wiley and sons, USA, p. 704.

33. Cochran GW, Cox GM (1992) Experimental Designs. ( $2^{\text {nd }}$ edn), John willey and Sons Inc, USA, p. 611.

34. Amadioha AC (2003) Evaluation of some Plants Leaf Extracts against Colletotrichum lindemuthianum in Cowpea. Acta Phytopathologia Entomologica Hungarica 38(3-4): 259-265.

35. Banso A, Adeyemo SO (2007) Evalution of antibacterial properties of tannins isolated from Dichrostachys cinerea. Afr J Biotechnol 6(15): 1785-1787.

36. Bobbarala VP, Katikala PK, Naidu KC, Penumajji S (2009) Antifungal activity of selected plant extracts against phytopathogenic fungi Aspergillus niger F2723. Ind J Science and Technol 2(4): 87-90.

37. Okigbo RN, Putheti R, Achusi CT (2009) Post-harvest deterioration of cassava and its control using extracts of Azadirachta indica and Afromonium meleguata. E-J Chem 6(4): 1274-1280.

38. Ijato JY (2011) Antimycotic effects of aqueous and ethanol plant extracts on yam rot pathogens in Ado-Ekiti, Nigeria. Academia Arena 3(1): 115-121.

39. Onifade AK (2002) Antifungal effect of Azadirachta indica A. Juss extracts on Collectotricum indemathianum. Global J Pure Appl Sci 6(3): 423-428.

40. Ogwulumba SI, Ugwuoke KI, Iloba C (2008) Prophylactic effect of pawpaw leaf and bitter leaf extracts on the incidence of foliar mycopathogens of groundnut (Arachis hypogaea L) in Ishiagu, Nigeria. Afr J Biotechnol 7(16): 2878-2880.

41. Suleiman MN (2010) Fungitoxic activity of neem and pawpaw leaves extracts on Alternaria Solani, causal organism of yam rots. Adv Environ Biol 4(2): 159-161.

42. Brull S, Coote P (1999) Preservative agents in foods. Mode of action and microbial resistance mechanisms. Int J Food Microbiol 50(1-2): 501-517.

43. Shiva RSK, Neeti S, Udaysree (2013) Antimicrobial Activity of Black Pepper (Piper nigrum L) Gl. Journal of Pharmacology 7 (1): 87-90.

44. Amadioha AC (2000) Fungitoxic effect of some of some extracts against Rhizopus oryzae causing rot of potato. Archives of Phytopathol and Plant Protection 33(6): 499-507.

45. Emua SA, Fajola AO (1983) Chemical control of two leaf spot diseases of cluster yam (Dioscorea dumetorum) caused by Cercospora contraria and Didymosphaeria donacina. Plant Disease 67: 389-391.

46. Wakocha RC, Okereke VC (2005) Fungitoxi activity of extracts of some medicinal plants on Sclerotium rolfsii, causal organism of the Basal stem rots diseases of Tomato. Nig Journ of Plt Protection 22: 106-110.

47. Amadioha AC, Markson AA (2007) Post harvest control of tuber rot by Botryodiplodia acerina using extracts of plant origin. Archives of Phytopathol and plant Protection 40(5): 359 -366.

48. Amienyo CA, Ataga AE (2006) Post harvest fungal diseases of sweet potato (Ipomoea batatas L Lam) tubers sold in selected markets in Rivers state, Nigeria. Science Africa 5(2): 95-98.

49. Banso A, Adeyemo So, Jeremiah P (1999) Antimicrobial properties of Vernonia amygdalina extract. J Appl Sci and Manag 3: 9-11.

50. Udo SE, Madunagu BE, Isemin CD (2001) Inhibition of growth and sporulation of fungal pathogens on sweet potato and yam by garlic extracts. Nigeria Journal of Botany 14: 35-39.

51. Eze CS (1984) Studies on storage rot of cocoyam (Colocasia esculenta L Schott) at Nsukka. MSc Dissertation, Dept of Botany, Univ of Nigeria, Nsukka, p. 73.

52. Ritchie B (1991) Practical techniques in plant pathology CAB. Walling ford, UK.

\section{Your next submission with Juniper Publishers will reach you the below assets}

- Quality Editorial service

- Swift Peer Review

- Reprints availability

- E-prints Service

- Manuscript Podcast for convenient understanding

- Global attainment for your research

- Manuscript accessibility in different formats

( Pdf, E-pub, Full Text, Audio)

- Unceasing customer service

Track the below URL for one-step submission https://juniperpublishers.com/online-submission.php 